\section{Response of Shallots to Mulching and Nitrogen Fertilization}

\author{
Kebede Woldetsadik ${ }^{1}$ \\ Alemaya University, P.O. Box 132, Alemaya, Ethiopia \\ Ulla Gertsson and Johan Ascard \\ Department of Crop Science, The Swedish University of Agricultural Sciences, \\ P.O. Box 44, SE-230 53 Alnarp, Sweden
}

Additional index words. straw mulch, plastic mulch, weed control, moisture conservation, Ethiopia

\begin{abstract}
Two field experiments were conducted with shallot (Allium cepa var. ascalonicum Baker) on heavy clay soil to evaluate growth and yield response to mulching and nitrogen fertilization under the subhumid tropical climate of eastern Ethiopia during the short and main rainy seasons of 1999 with rainfalls amounting to 240 and $295 \mathrm{~mm}$, respectively. The treatments included wheat straw, clear and black plastic mulches, and an unmulched control, each with nitrogen rates of 0,75 , or $150 \mathrm{~kg} \cdot \mathrm{ha}^{-1}$. Straw and black plastic mulches increased soil moisture while clear plastic reduced it considerably. Weed control was best with black and clear plastics in the short season and with black plastic or straw mulch in the main season. Both plastic mulches elevated soil temperature, especially clear plastic, which also caused most leaf tip burn. Yield increased nearly three-fold with the black plastic mulch in the short season and by one fourth in the main season compared to the bare ground. The straw and clear plastic mulches increased yield during the short season, but slightly reduced yield in the main season. The growth and yield of shallot were related to the weed control and soil moisture conservation efficiency of the mulches. Mulching did not alter the dry matter and the total soluble solids contents of the bulbs. Nitrogen fertilizer increased leaf numbers, plant height, mean bulb weight, bulb dry matter, and total soluble solids while reducing marketable bulb number, but did not significantly affect yield, leaf tip burn, or weed abundance.
\end{abstract}

In Ethiopia, shallots are one of the most important and widely used vegetables. The major production areas in the country are characterized by a bi-modal rainfall distribution. The main rainy season occurs between July and September, followed by a long dry period that is interrupted by small rains (short season) peaking in April. Most growers plant shallot bulbs at the onset of the small rains. However, rainfall is usually irregular and the season is relatively warm, which could increase evapotranspiration of the plants (El-Habbasha and Shaheen, 1976; Prashar, et al., 1994; Talha, et al., 1978). As a result, shallot crops often face moisture stress at early or peak growth periods. Similarly, the second crop planted in the main season may also be moisture stressed as growers delay planting because of risk of fungal diseases such as downy mildew and purple blotch during the high rainfall period (personal observation).

Shallot growers often apply high amounts of nitrogen fertilizer $\left(150 \mathrm{~kg} \cdot \mathrm{ha}^{-1}\right)$ in an attempt to obtain high yields. Nitrogen fertilizers enhance growth and yield of shallow rooted onion crops (Brewster, 1990; Hegde, 1986; Suojala et al, 1998). Such benefits can be realized when the vegetation period is sufficiently long and when

Received for publication 12 Dec. 2001. Accepted for publication 8 May 2002.

${ }^{1}$ To whom reprint requests should be addressed. Current address: c/o Ulla.gertsson. E-mail Ulla.gertsson@vv.slu.se Fax: +46 40415353 there is no severe drought, especially during the bulbing stage (Brewster, 1990; Doorenbos and Kassam, 1979). However, no data are available to substantiate the belief that benefits can be obtained from fertilization of shallots under low soil moisture conditions.

Cultivation of crops without sufficient precipitation or irrigation demands efficient ways of utilizing any water reserves available to the plant. Results of different kinds of mulching materials under different soil and climatic conditions indicate increased plant growth and yields and improved bulb size of onions. Many of these effects were attributed to the capacities of the mulch in conserving soil moisture (Abu-Awwad, 1999; Adetunji, 1994; Shock et al., 1999), increasing soil temperature (Rahman and Khan, 2001), controlling weeds and diseases (Durante and Cuocolo, 1989; Katan etal., 1980; Shock etal., 1997), and reducing loss of nutrients (Shock et al., 1997).

Although mulching with plant residues has been a well-established practice, its use in some subhumid tropical areas is limited since these residues are used for other purposes, such as feed, fuel, or construction material. The use of polyethylene (plastic) mulch in such areas could be an alternative means for successful production of vegetables. Plastic mulches of different colors have been reported for their efficiency in increasing yields of onions (Abdel, 1990; Adetunji, 1994; Vavrina and Roka, 2000).

This study was initiated to evaluate the effect of different types of mulches on weed growth, soil moisture conservation, and soil temperature and on growth, yield and quality of shallots; and to evaluate the effects of nitrogen fertilization on growth, yield and quality of the crop under the subhumid tropical climate of Ethiopia.

\section{Materials and Methods}

Two field experiments were conducted during the short rainy season and main rainy season of 1999 on the Research Farm of the Alemaya Univ. of Agriculture, Ethiopia (lat. $42^{\circ} 3^{\prime} \mathrm{E}$; long. $9^{\circ} 26^{\prime} \mathrm{N}$ ) at an altitude of $1980 \mathrm{~m}$ above sea level. Soil of the site was a heavy clay with $15 \mathrm{~g} \cdot \mathrm{kg}^{-1}$ organic carbon, $1.5 \mathrm{~g} \cdot \mathrm{kg}^{-1}$ total nitrogen $(\mathrm{N}), 0.007 \mathrm{~g} \cdot \mathrm{kg}^{-1}$ available phosphorus (P), $\mathrm{pH} 7.2$, and water holding capacities of $420 \mathrm{~g} \cdot \mathrm{L}^{-1}$ and $260 \mathrm{~g} \cdot \mathrm{L}^{-1}$ at field capacity and permanent wilting points, respectively.

The short season planting was carried out soon after rain commenced on 16 Apr. and the main season planting was carried out on 24 Sept. 1999, following the rainfall pattern and growers' practices. Rainfalls during crop growth periods of the first and the second experiments were 240 and $295 \mathrm{~mm}$, respectively. Mean air temperatures during respective periods were 19.1 and $15.3{ }^{\circ} \mathrm{C}$.

Bulbs of a local shallot cultivar, 'DZTSht-78', with a size of $\approx 30 \mathrm{~mm}$ were used in the studies. Treatments comprised four mulch materials and three nitrogen fertilizer levels. The mulch treatments were bare ground, wheat straw, and black and clear polyethylene sheets $(0.03 \mathrm{~mm})$ each with nitrogen $(\mathrm{N})$ applications at rates of 0,75 , and $150 \mathrm{~kg} \cdot \mathrm{ha}^{-1}$. The source of $\mathrm{N}$ was urea. All combinations of the mulch and nitrogen levels were laid out in field plots in a randomized complete-block design with four replications. Plots consisted of four 0.6 -m-wide $\times 3$-m-long beds and a path of 1.5 $\mathrm{m}$ between the plots. Planting was done in two rows per bed at a spacing of $0.3 \mathrm{~m}$ between rows and $0.2 \mathrm{~m}$ between plants in the row. The outer beds were used as borders and for monitoring soil moisture while the two center beds were used plant growth, weed, and yield measurements.

The nitrogen treatments were applied to the appropriate plots before mulching. At the same time, all plots received triple superphosphate equivalent to $\mathrm{P}$ at the rate of $40 \mathrm{~kg} \cdot \mathrm{ha}^{-1}$. The fertilizers were thoroughly mixed with the topsoil. The plastic mulch treatments were placed on top of the ridged beds and anchored with hooked sticks and loose soil along the outer edge and center of the furrows after cutting planting holes. A narrow strip (20-30 $\mathrm{mm}$ ) along the center of the furrow was left uncovered to let rain water percolate into the soil. The wheat straw mulch ( $50 \mathrm{~mm}$ thick) was uniformly spread on the plots after planting.

The soil moisture content of the plots at $0.1 \mathrm{~m}$ depth in the bed was determined using a TDR moisture meter (Trime FM-3; IMKO, Ettlingen, Germany) at weekly intervals in the main season experiment. However, during the first experiment, measurements were made gravimetrically at monthly intervals with soil samples randomly taken from the border 
rows. Soil temperature at a depth of $0.1 \mathrm{~m}$ in the beds and from five spots per plot was also recorded once a week at 1100 and $1400 \mathrm{HR}$ using a thermometer with attached probe (Testo 110; Nordtec Sensor Technologies AB, Linkoping, Sweden) throughout the experiments.

Weed infestation levels were determined by visual comparison of the weed density in the plant holes with a 1-5 rating, where the scale represented weed populations of $<10$, $10-50,>50-100,>100-200$, and $>200 \mathrm{~m}^{-2}$, respectively. The scoring was done at 4,6 , and 8 weeks after planting and the weeds were removed after each assessment.

Data on plant height, leaf numbers and laterals were recorded on 20 plants per plot, 8 weeks after planting when plants attained nearly maximum foliage growth. Assessment of leaf tip burn was made as percent of white tip incidence following the procedure of Leong (1986) at 6 and 8 weeks after planting. Bulbs were harvested when nearly $80 \%$ of the tops had withered. Marketable bulbs were graded by diameter into small, medium, and large (20-35, >35-50, >50 mm, respectively). Injured and small bulbs $<20 \mathrm{~mm}$ diameter were recorded separately. Dry matter content was determined by chopping one-quarter pieces of 10 bulb samples randomly taken from each treatment, and oven drying them at $75^{\circ} \mathrm{C}$ to a constant weight. From the remaining quarters, juice was extracted with a garlic press and total soluble solids (TSS) were determined using Abbe 60 refractometer (Bellingham \& Stanley, Tunbridge Wells, U.K.). Tissue nitrogen was determined by the macro-Kjeldahl method (AOAC, 1984).

The analyses of variance were carried out using the general linear model of Minitab Statistical Software (Minitab, State College, $\mathrm{Pa}$.) with comparison of means using least significant difference (LSD) test at the 5\% level. Regression analysis was used to test correlation between plant growth characters.

\section{Results}

Mulching significantly affected most of the soil and plant parameters considered in this study. The use of wheat straw and black plastic increased plant height by $21 \%$ and $42 \%$, respectively, compared with unmulched plants (Table 1). Plants grown with clear plastic were significantly shorter than those of all other treatments. The use of black plastic significantly increased leaf nitrogen $(\mathrm{N})$ content and bulb $\mathrm{N}$ uptake of shallot plants, while the straw mulch significantly reduced $\mathrm{N}$ contents in the leaves.

Mulching showed interactive effects with season on leaf tip burn, bulb number, bulb weight, yield, and weed infestation levels (Table 2). The use of straw or black plastic mulch significantly reduced the level of tip burn compared with control plants. However, plants grown in clear plastic mulch showed significantly more tip burn than all other treatments. Except in the control and straw mulched plants, leaf tip burn was significantly higher in the main season compared with the short season. Bulb numbers were significantly higher in the main season than in the short season. In the main season, the

Table 1. Main effect of mulching on plant height, leaf and bulb $\mathrm{N}$ contents and $\mathrm{N}$ uptake by shallot. Means averaged over two seasons and three $\mathrm{N}$ rates. ${ }^{2}$

\begin{tabular}{lcccc}
\hline $\begin{array}{l}\text { Mulch } \\
\text { treatment }\end{array}$ & $\begin{array}{c}\text { Plant height } \\
(\mathrm{mm})\end{array}$ & $\begin{array}{c}\text { Leaf N } \\
\left(\mathrm{g} \cdot \mathrm{kg}^{-1}\right)\end{array}$ & $\begin{array}{c}\text { Bulb N } \\
\left(\mathrm{g}^{\mathrm{kg}} \mathrm{kg}^{-1}\right)\end{array}$ & $\begin{array}{c}\text { Bulb N uptake } \\
\left(\mathrm{kg} \cdot \mathrm{ha}^{-1}\right)\end{array}$ \\
\hline Bare ground & 272 & 26 & 20 & 26 \\
Wheat straw & 329 & 15 & 19 & 31 \\
Clear plastic & 244 & 23 & 19 & 25 \\
Black plastic & 386 & 34 & 20 & 47 \\
LSD $_{0.05}$ & 17 & 4 & NS & 8 \\
\hline
\end{tabular}

${ }^{2}$ Leaf and bulb $\mathrm{N}$ and bulb $\mathrm{N}$ uptake for main season only.

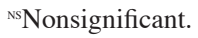

Table 2. Effects of mulch type and season on shallot plant growth, yield, and weed infestation. Means averaged over three nitrogen rates

\begin{tabular}{|c|c|c|c|c|c|}
\hline $\begin{array}{l}\text { Mulch } \\
\text { treatment }\end{array}$ & $\begin{array}{c}\text { Leaf tip burn } \\
(\%)\end{array}$ & $\begin{array}{l}\text { Bulb no. } \\
\text { per plant }\end{array}$ & $\begin{array}{l}\text { Bulb } \\
\text { wt (g) }\end{array}$ & 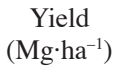 & $\begin{array}{l}\text { Weed } \\
\text { score }^{2}\end{array}$ \\
\hline \multicolumn{6}{|c|}{ Short season } \\
\hline Bare ground & 8.2 & 3.5 & 11.5 & 5.8 & 3.1 \\
\hline Wheat straw & 4.0 & 3.7 & 21.0 & 10.8 & 2.9 \\
\hline Clear plastic & 12.0 & 3.6 & 14.6 & 7.1 & 2.5 \\
\hline Black plastic & 3.0 & 3.5 & 31.8 & 16.3 & 1.2 \\
\hline \multicolumn{6}{|c|}{ Main season } \\
\hline Bare ground & 7.2 & 7.3 & 12.3 & 9.4 & 3.1 \\
\hline Wheat straw & 4.9 & 5.7 & 14.2 & 8.4 & 2.2 \\
\hline Clear plastic & 13.5 & 6.8 & 11.8 & 8.6 & 3.6 \\
\hline Black plastic & 4.6 & 7.9 & 13.3 & 11.9 & 1.5 \\
\hline LSD $_{005}$ & 1.2 & 0.8 & 2.2 & 1.7 & 0.3 \\
\hline
\end{tabular}

straw mulch significantly reduced bulb number compared to all other treatments.

Black plastic and straw mulch significantly increased bulb weight and yield of shallot during the short season compared to the bare plot(Table $2)$. The bulb weight and yield increases were nearly 3 -fold for the black plastic mulch and 2fold for the straw mulch treatment. In the main season, a yield increase was achieved only from the black plastic mulch, while bulb weight was significantly higher in the straw mulch compared to the bare plot. The proportion of large bulbs $(>50 \mathrm{~mm}$ ) followed a similar trend to bulb yield in the short season, being highest in the black plastic mulch followed by straw and least in clear plastic and the bare treatments (Fig. 1).

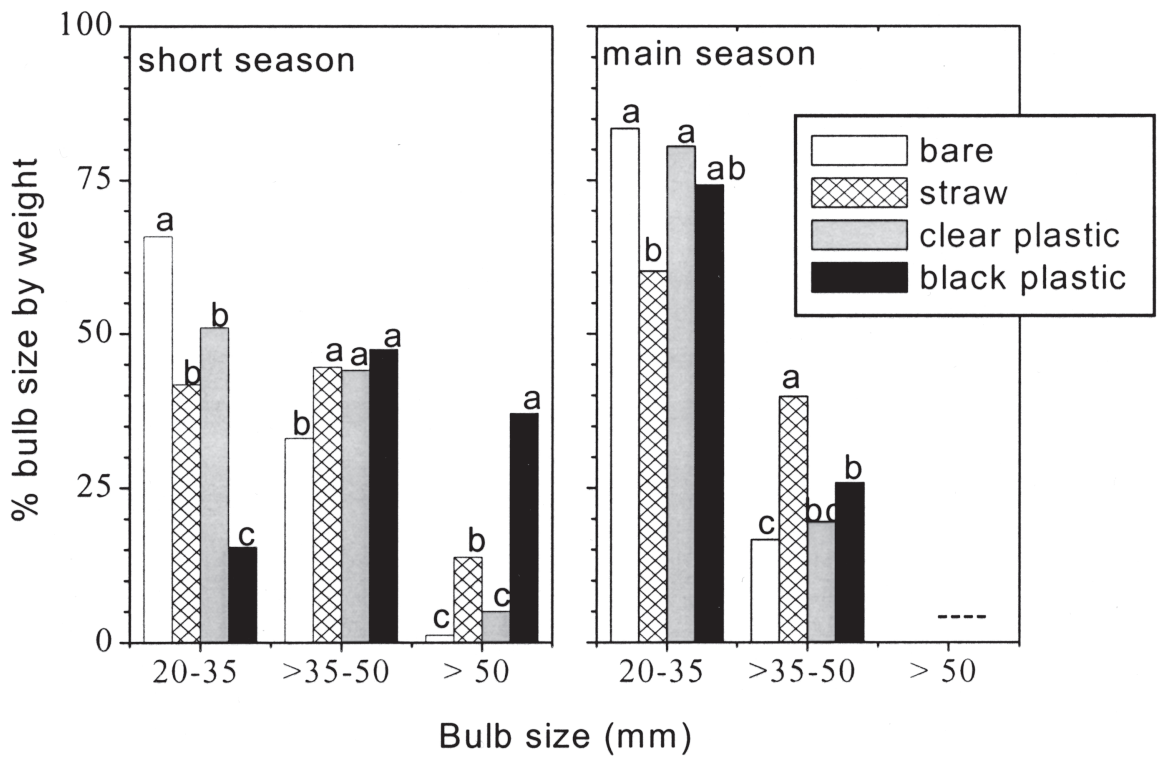

Fig. 1. Bulb size distribution of shallot with mulching treatments in the short and main seasons. Bulb with $>50 \mathrm{~mm}$ in the main season were very few. Means with the same letter in each bulb category are not significantly different $\left(\mathrm{LSD}_{0.05}\right)$. 
reduced numbers of weeds in the short season, while it increased them in the main season. The weed control effect of the straw mulch was better than the bare plot only during the main season.

Nitrogen application significantly increased plant height at rate of $75 \mathrm{~kg} \cdot \mathrm{ha}^{-1}$ and bulb $\mathrm{N}$ content and $\mathrm{N}$ uptake at rates of 75 or $150 \mathrm{~kg} \cdot \mathrm{ha}^{-1}$ (Table 3 ). Bulb numbers were significantly reduced at $\mathrm{N}$ rate of $150 \mathrm{~kg} \cdot \mathrm{ha}^{-1}$. Application of $\mathrm{N}$ did not significantly affect bulb yield, leaf $\mathrm{N}$ contents, leaf tip burn, or weed population (data not shown).

Nitrogen and season showed interactive effects on bulb weight and DM content of bulbs (Table 4). Bulbs were heavier in the short season crop than in the main season crop and $\mathrm{N}$ rate at $75 \mathrm{~kg}$ gave the highest mean bulb weight. The DM content of the main season crop was higher than that of the short season and bulb $\mathrm{DM}$ at $\mathrm{N}$ rate of $150 \mathrm{~kg} \cdot \mathrm{ha}^{-1}$ was highest during the main season.

Nitrogen also showed interactive effects with mulching on leaf number and bulb DM contents (Table 5). Both leaf numbers and $\mathrm{DM}$ tended to increase with $\mathrm{N}$ rate except in black plastic mulched plants. Unfertilized, black plastic mulched plots gave the highest leaf number while unfertilized bare plots and clear plastic mulched plots gave the least. Straw mulched and bare plots at $\mathrm{N}$ rate of $75 \mathrm{~kg} \cdot \mathrm{ha}^{-1}$ and clear plastic at $\mathrm{N}$ rate of $75 \mathrm{~kg} \cdot \mathrm{ha}^{-1}$ gave the highest DM contents of bulbs.

The season, mulching, and $\mathrm{N}$ fertilizer interaction showed significant three-way interactive effects only on TSS of bulbs where bare plots at all levels of $\mathrm{N}$ and black plastic mulched plots at $\mathrm{N}$ rates of $150 \mathrm{~kg} \cdot \mathrm{ha}^{-1}$ resulted in the highest TSS of bulbs (Table 6) during the main season. In the short season, the TSS content of bulbs in all mulched plots did not differ from the bare plots, but black plastic mulch tended to reduce it at all levels of $\mathrm{N}$.

Soil moisture at a 0.1-m depth was significantly higher under the straw treatments during most part of the growing seasons compared with the bare plots (Fig. 2). Soil moisture under the black plastic treatment was also significantly higher during the fourth week in the short season and sixth and eighth weeks in the main season compared with the bare plots. Soil moisture in clear plastic mulched plots was either similar to or lower than that of the bare plots in both seasons.

Clear and black plastic mulches significantly raised the soil temperature at a $0.1-\mathrm{m}$ depth during most part of the growing seasons, while straw reduced it compared with the bare ground treatments (Fig. 3). With clear plastic, the rise averaged $3{ }^{\circ} \mathrm{C}$ in both seasons and ranged between 1.1 and $6.5^{\circ} \mathrm{C}$. While the increase by black plastic over the seasons was $\approx 1.5^{\circ} \mathrm{C}$, the straw mulch on average reduced soil temperature by $2{ }^{\circ} \mathrm{C}$.

\section{Discussion}

The yield increases of shallot by black plastic in this study could, in part, be attributed to the combined effect of weed control, conservation of soil moisture, and increase in soil temperature.

Table 3. Main effect of $\mathrm{N}$ on plant height, bulb number, yield, leaf and bulb $\mathrm{N}$ contents and $\mathrm{N}$ uptake of shallot. Means averaged over two seasons and four mulching treatments ${ }^{\mathrm{z}}$

\begin{tabular}{lcccc}
\hline $\begin{array}{l}\text { Nitrogen } \\
\left(\mathrm{kg} \cdot \mathrm{ha}^{-1}\right)\end{array}$ & $\begin{array}{c}\text { Plant ht. } \\
(\mathrm{mm})\end{array}$ & $\begin{array}{c}\text { Bulb no. } \\
\text { per plant }\end{array}$ & $\begin{array}{c}\text { Bulb N } \\
\left(\mathrm{g} \cdot \mathrm{kg}^{-1}\right)\end{array}$ & $\begin{array}{c}\text { Bulb N uptake } \\
\left(\mathrm{kg} \mathrm{ha}^{-1}\right)\end{array}$ \\
\hline 0 & 298 & 5.6 & 16 & 27 \\
75 & 318 & 5.4 & 20 & 36 \\
150 & 307 & 4.8 & 22 & 35 \\
LSD $_{0.05}$ & 14 & 0.5 & 2 & 7 \\
\hline
\end{tabular}

${ }^{\mathrm{z}}$ Leaf and bulb $\mathrm{N}$ and bulb $\mathrm{N}$ uptake for main season only.

Table 4. Effects of $\mathrm{N}$ rate and season on bulb weight and bulb dry matter (DM) content of shallot.

\begin{tabular}{|c|c|c|c|c|}
\hline \multirow{2}{*}{$\begin{array}{l}\text { N rate } \\
\left(\mathrm{kg} \mathrm{ha}^{-1}\right)\end{array}$} & \multicolumn{2}{|c|}{ Bulb wt (g) } & \multicolumn{2}{|c|}{$\mathrm{DM}\left(\mathrm{g} \cdot \mathrm{kg}^{-1}\right)$} \\
\hline & Short season & Main season & Short season & Main season \\
\hline 0 & 18.5 & 12.6 & 152 & 164 \\
\hline 75 & 20.6 & 13.0 & 153 & 171 \\
\hline 150 & 20.1 & 13.2 & 149 & 177 \\
\hline $\operatorname{LSD}_{0.05}{ }^{\mathrm{z}}$ & \multicolumn{2}{|c|}{1.9} & \multicolumn{2}{|c|}{5} \\
\hline
\end{tabular}

Although the moisture conservation efficiency of the straw mulch was equivalent to, or better than, that of black plastic, its effect on yield did not match that of the black plastic mulch. This could be due to the lower soil temperature in the straw plot. Leaf and bulb growth of onion plants are linearly correlated to temperature from 6 to $27^{\circ} \mathrm{C}$ (Brewster, 1994). Grubben (1990) indicated that the temperature optimum for shallot cultivation in Indonesia was $\approx 24{ }^{\circ} \mathrm{C}$ with a range between 20 and $30{ }^{\circ} \mathrm{C}$. However, the high soil temperature coupled with heavy weed infestation in clear plastic mulched plots resulted in consistently low soil moisture throughout the seasons which could have accounted for the reduced foliage and high incidence of leaf tip burn and consequently yields similar or lower than the bare plots. Leong (1986) has also reported similar yield-depressing effects of leaf tip burn associated with moisture stress in shallots.
The reduction in soil temperature by straw and increase by the plastic mulches is in agreement with previous reports (Asiegbu, 1991; Bonanno and Lamont, 1987; Tindall et al, 1991).

The association of leaf numbers and plant height to the availability of soil moisture and theireffect on yield is in agreement with previous reports for onions (El-Habbasha and Shaheen, 1976; Talha et al, 1978; Begum et al, 1990). Shallot bulb yield in the present study showed significant correlation with bulb weight $(r=$ $0.84 ; P<0.001)$, which in turn was associated to the numbers of leaves $(r=0.78 ; P<0.001)$ and height of the plants $(r=0.90 ; P<0.001)$.

Nitrogen fertilizer slightly improved mean bulb weight and bulb DM and TSS contents. However, it did not increase marketable yield in both seasons; rather, additional nitrogen promoted foliage growth, delayed bulb growth and development, and reduced the number of

Table 5. Effects of mulch type and $\mathrm{N}$ rate on shallot leaf number and bulb dry matter (DM) content.

\begin{tabular}{|c|c|c|c|c|c|c|}
\hline \multirow{3}{*}{$\begin{array}{l}\text { Treatments } \\
\text { Mulch }\end{array}$} & \multicolumn{3}{|c|}{ Leaves per plant } & \multicolumn{3}{|c|}{$\mathrm{DM}\left(\mathrm{g} \cdot \mathrm{kg}^{-1}\right)$} \\
\hline & \multicolumn{6}{|c|}{$\overline{\mathrm{N}}$ rate $\left(\mathrm{kg} \cdot \mathrm{h \textrm {a } ^ { - 1 }}\right)$} \\
\hline & 0 & 75 & 150 & 0 & 75 & 150 \\
\hline Bare ground & 17 & 21 & 19 & 159 & 166 & 162 \\
\hline Wheat straw & 21 & 21 & 22 & 156 & 167 & 161 \\
\hline Clear plastic & 18 & 22 & 22 & 155 & 161 & 166 \\
\hline Black plastic & 30 & 29 & 27 & 161 & 154 & 162 \\
\hline $\operatorname{LSD}_{0.05}{ }^{\mathrm{z}}$ & & 2.6 & & & 8 & \\
\hline
\end{tabular}

Table 6. Effects of mulch type, $\mathrm{N}$ rate, and season on shallot bulb total soluble solids $\left(\mathrm{g} \mathrm{kg}^{-1}\right)$ contents.

\begin{tabular}{|c|c|c|c|c|c|c|}
\hline \multirow{3}{*}{$\begin{array}{l}\text { Treatments } \\
\text { Mulch }\end{array}$} & \multicolumn{3}{|c|}{ Short season } & \multicolumn{3}{|c|}{ Main season } \\
\hline & \multicolumn{6}{|c|}{$\mathrm{N}$ rate $\left(\mathrm{kg} \cdot \mathrm{ha}^{-1}\right)$} \\
\hline & 0 & 75 & 150 & 0 & 75 & 150 \\
\hline Bare ground & 124 & 126 & 125 & 150 & 150 & 155 \\
\hline Wheat straw & 131 & 131 & 127 & 148 & 147 & 143 \\
\hline Clear plastic & 136 & 124 & 124 & 140 & 147 & 140 \\
\hline Black plastic & 125 & 120 & 117 & 138 & 148 & 157 \\
\hline $\operatorname{LSD}_{0.05}{ }^{\mathrm{z}}$ & \multicolumn{3}{|c|}{8} & & & \\
\hline
\end{tabular}

HortScience, Vol. 38(2), April 2003 


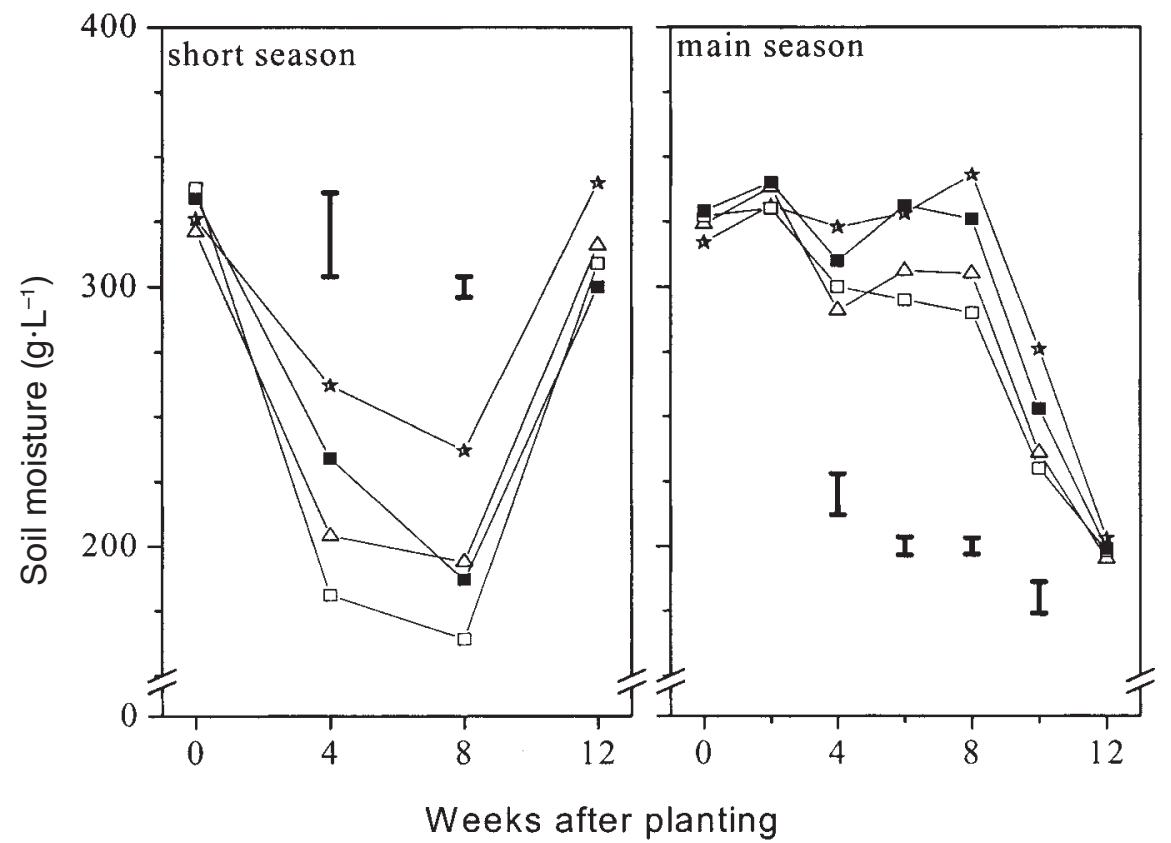

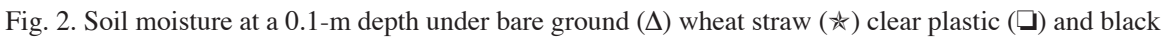
plastic ( $\square$ ) mulches in the short and main seasons. Vertical bars indicate LSD at $P=0.05$.

marketable bulbs. The absence of response of shallot plants to applied nitrogen in this study is possibly due to the low soil moisture that prevailed during most of the growing period in the short season and relatively low soil temperature in the main season. Although there were differences between the treatments, none of the mulch materials kept root zone soil moisture above the wilting point during the fourth and eighth week after planting in the short season. In the main season too, reduced soil moisture during the second half of the crop-growing period as well as low air and soil temperatures limited bulb growth. Mean air temperatures during the short and main seasons were 19.1 and $14.8^{\circ} \mathrm{C}$, respectively, and the soil temperature of the main season was $4.3^{\circ} \mathrm{C}$ lower than that of the short season, which is sub-optimal for shallot cultivation (Grubben, 1990).

The effect of mulching was not sufficiently great to allow the crop to utilize applied $\mathrm{N}$ under rain-fed conditions, although the soil was naturally low in fertility. Because of their shallow-rooted nature, growth and yield of onion plants are normally affected when the available soil moisture in the topsoil surface drops below $60 \%$ to $80 \%$ available soil moisture (Brewster, 1990; Shock et al., 1998). The work of Hegde (1986) and Thabet et al. (1994) also showed no or little growth and yield responses of onion plants to nitrogen fertilization under low soil moisture regimes. Application of fertilizer in this

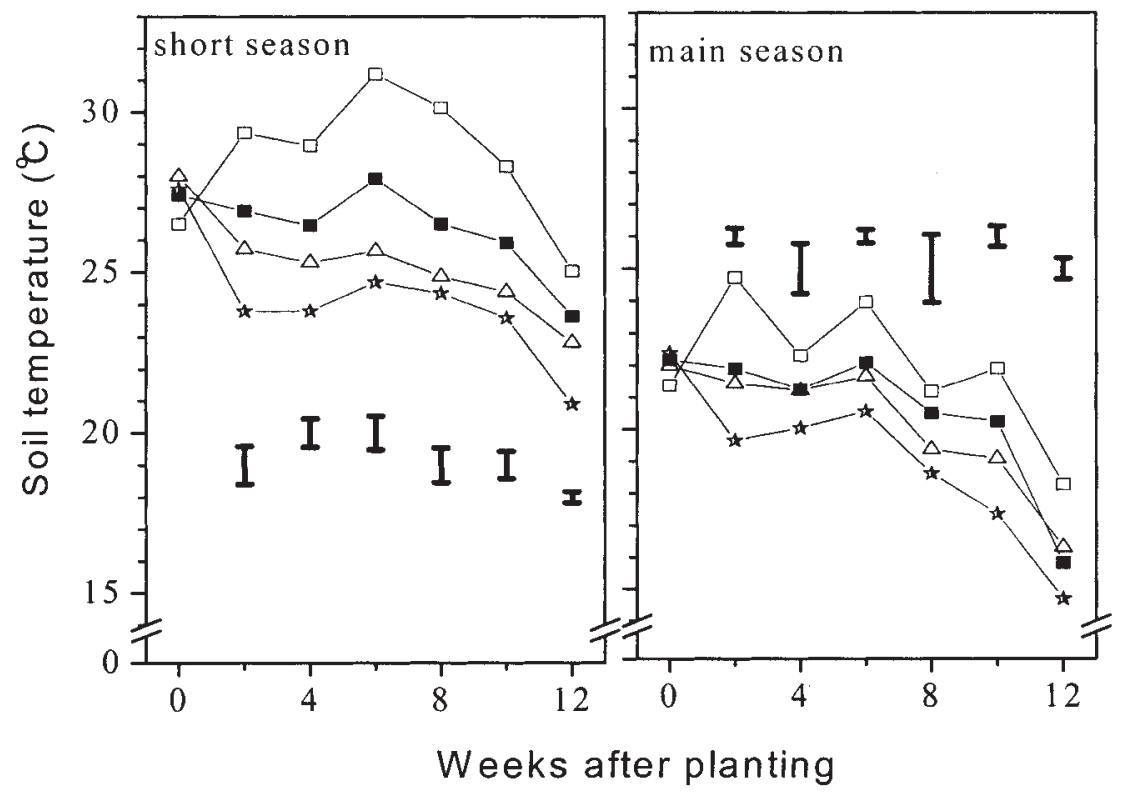

Fig. 3. Soil temperature at a 0.1 -m depth under bare ground $(\Delta)$ wheat straw $(\star)$ clear plastic $(\square)$ and black plastic ( $\square)$ mulches in the short and main seasons. Vertical bars indicate LSD at $P=0.05$. study would have aggravated stress around the plants due to concentration of ions.

Result of this study indicate that moisture conservation alone by black plastic mulch can double yield of rain-fed shallot. However, application of nitrogen, tended to reduce yield. Use of supplemental irrigation and a wider range of cultivars may be considered for potential response of the crop to $\mathrm{N}$ fertilization.

\section{Literature Cited}

Abdel, C.G. 1990. The influence of mulching on irrigated and non-irrigated onion cultivations. Mesopotamia J. Agr. 22:25-33.

Abu-Awwad, A.M. 1999. Irrigation water management for efficient water use in mulched onion. J. Agr. Crop Sci. 183:1-7.

Adetunji, I.A. 1994. Response of onion to soil solarization and organic mulching in semi-arid tropics. Sci. Hort. 60:161-166.

AOAC. 1984. Official methods of analysis. Assn. of Official Analytical Chemists, Washington, D.C.

Asiegbu,J.E. 1991. Reponse of tomato and eggplant to mulching and nitrogen fertilization under tropical conditions. Sci. Hort. 46:33-41.

Begum, R.A., S.A. Mallik, M. Rahman, M.N. Anowar, and M.S. Khan. 1990. Yield response of onion as influenced by different soil moisture regimes. Bangladesh J. Agr. Res. 15:64-69.

Bonanno, A.R. and W.J. Lamont. 1987. Effect of plastic mulches, irrigation method, and row covers on soil and air temperature and yield of muskmelon. J. Amer. Soc. Hort. Sci. 112: 735-738.

Brewster, J.L., 1990. Cultural systems and agronomic practices in temperate climates. In: H.D. Rabinowitch and J.L. Brewster (eds.). Onions and Allied Crops, Vol. II. CRC Press, Boca Raton, Fla.

Brewster, J.L. 1994. Onions and other vegetable Alliums. CAB Intl., U.K.

Doorenbos, J. and A.H. Kassam. 1979. Yield response to water. F.A.O. Irrigation and drainage, paper no. 33, Rome.

Durante, A. and L. Cuocolo. 1989. Chemical weed control and mulching in onion (Allium cepa L.) and garlic (Allium sativum L.). Adv. Hort. Sci. 1:7-12.

El-Habbasha, K.M. and A.M. Shaheen. 1976. Growth, photosynthetic efficiency, water and nitrogen contents of onion (Allium cepa) seedlings, affected by water deficit in the soil. J. Agron. Crop Sci. 142:256-263.

Grubben, G.J.H. 1990. Timing of vegetable production in Indonesia. Acta Hort. 267: 261-270.

Hegde, D.M. 1986. Growth analysis of onion (Allium серa) in relation to irrigation and nitrogen fertilization. J. Agron. Crop Sci. 157: 227-234.

Katan, J., I. Rotem, Y. Finkel, and J. Daniel. 1980. Solar heating of the soil for the control of pink root and other soil-borne diseases in onions. Phytoparasitica 8:39-50.

Leong, A.C. 1986. The effects of frequencies and levels of watering on the performance of shallot (Allium cepa var. ascalonicum) grown on peat. Malaysian Agr. Res. Dev. Inst. Res. Bul. 14:29-33

Prashar, C.R.K., G.C. Sharma, and M. Gandah. 1994. Evapotranspiration of onion in Sahelian Niger. Expt. Agr. 30:473-476.

Rahman, M.S. and M.A.H. Khan. 2001. Mulching- 
induced alteration of microclimatic parameters on the morpho-physiological attributes in onion (Allium cepa L.). Plant Production Sci., Bangladesh 4:241-248.

Shock,C.C.,E.B.G. Feibert and L.D. Saunders. 1998 Onion yield and quality affected by soil water potential as irrigation threshold. HortScience 33:1188-1191.

Shock, C.C, J.H. Hobson, M. Seddigh, B.M Shock, T.D. Stieber, and L.D. Saunders. 1997. Mechanical straw mulching of irrigation furrows: Soil erosion and nutrient losses. Agron. J. 89:887-893.
Shock, C.C., L.B. Jensen, J.H. Hobson, M. Seddigh, B.M. Shock, L.M. Saunders, and T.D. Stieber 1999. Improving onion yield and market grade by mechanical straw application to irrigation furrows. HortTechnology 9:251-253.

Soujala, T., T. Salo, and R. Pessala. 1998. Effect of fertilization and irrigation practices on yield, maturity and storability of onions. Agr. Food Sci., Finland 7:477-489.

Talha, M., H. Hamdi, and M. Semaik. 1978. Evapotranspiration and yield of onion and beans as affected by soil texture and available soil moisture depletion. Egyptian J. Soil Sci. 18:1-10.
Thabet, E.M.A, A.A.G. Abdallah, and A.A.G. Mohamed. 1994. Productivity of onion grown in reclaimed sandy soil using Tafla as affected by water regimes and nitrogen levels. Ann. Agr. Sci. Ain-Shams Univ., Egypt. 39:337-344.

Tindall, J.A., R.B. Beverly, and D.E. Radcliffe. 1991. Mulch effects on soil properties and tomato growth using micro-irrigation. Agron. J. 83:1028-1034.

Vavrina, C.S. and F.M. Roka. 2000. Comparison of plastic mulch and bare-ground production and economics for short-day onions in a semi-tropical environment. HortTechnology 10:326-330. 